\title{
Pedagogical Conditions for the Formation of Graphic Culture of School Students in the Process of Using Computer Technologies
}

\author{
Dmitrii Grinev \\ College \\ Pskov State University \\ Pskov, Russia \\ grinev_dmitry@mail.ru
}

\author{
Igor Savraev \\ Department of Electric Power, \\ Electric Drive and Automation \\ Systems \\ Pskov State University \\ Pskov, Russia \\ igor_savraev@mail.ru
}

\author{
Natalia Shlat \\ Institute of Education and Social \\ Sciences \\ Pskov State University \\ Pskov, Russia \\ NataliaShlat@gmail.com
}

\begin{abstract}
The aim of the study is the scientific and experimental identification of a complex of effective pedagogical conditions for the formation of the graphic culture of school students in the process of using computer technologies. In the article, based on the analysis of the structure of graphic culture in the system of the general culture of the personality of a student of the XXI century, as well as identifying the features of the use of computer technologies in modern school education, the effectiveness of creating pedagogical conditions for the formation of the graphic culture of school students is theoretically and experimentally substantiated: the use of a complex of program-methodological and pedagogical teaching aids using computer technology, the implementation of an active learning model in the organization of educational activities and the interaction of the teacher and students in the classroom. The article describes an empirical study of the conditions for the formation of the graphic culture of school students in sketching lessons: the diagnosed parameters are determined, a comprehensive test of the level of graphic culture in secondary school students is carried out, an assessment of the effectiveness of the influence of a complex of pedagogical learning conditions on the formation of the graphic culture of students is given. The experiment revealed the need to create special pedagogical conditions that form the basis for the development and implementation of the elective course program "Technical Sketching Using CAD”.
\end{abstract}

Keywords - computer technology, graphic culture, pedagogical condition, school education.

\section{INTRODUCTION}

Informatization of all spheres of human life, on the one hand, simplified the solution of the problems of collecting, processing, interpreting and transmitting information, visualizing images in relation to various fields of science and technology; on the other hand, it showed the importance and meta-subjectness (interdisciplinarity) of information culture, which was initially interpreted in the context of the optimal organization of human intellectual activity.

Information culture acts as a phenomenon that reflects a special, virtual culture, which includes many spaces [1] from communication to network, - which affect the culture of a person's personality, in general, and modify it, taking into account the requirements of optimal orientation in the information picture of the world, adaptation in the information society.

I. V. Chugunova [2] in the structure of the general culture of the student's personality, in addition to moral, environmental, informational and other types of culture, distinguishes graphic culture as the highest degree of skill in transforming graphic objects and mastering the graphic language. At the same time, a truly "personal component" is emphasized - the ability to self-expression - which fills the concept of "graphic culture" with axiological meaning.

Following I. V. Chugunova [2], the authors of the graphic culture of school students will be interpreted as a set of educational and personal achievements in the field of mastering and using graphic methods of transforming information. The author's contribution to the definition of the concept of "graphic culture of a schoolchild" consists in concretizing its structural components and their functions, as well as in clarifying the content and 
experimentally checking the level of actualization of each component under the influence of specially created conditions.

As the educational practice and research of A. A. Temerbekova and G. V. Bajkunakova [3] show, the level of graphic knowledge of students is quite low, which is explained by the lack of relevant content in the curriculum, as well as the uncertainty of the conditions for broadcasting content aimed at the formation of a graphic culture (M. V. Nepobednyj, A. P. Sysoev, and E. A. Mramornova [4]).

Thus, the aim of the study is the scientific and experimental identification of a complex of effective pedagogical conditions for the formation of the graphic culture of school students in the process of using computer technologies.

\section{MATERIALS AND METHODS}

In the course of the research, a set of methods was used: analysis and generalization of scientific views on the problem of finding relevant conditions for the formation of the graphic culture of school students in the process of using computer technologies, a pedagogical experiment, testing of students, and generalization of work results.

Graphic culture in research is considered as:

- a set of achievements of society in the field of creating and mastering graphic methods of displaying, storing, transmitting geometric, technical and other information about the objective world (I. V. Chugunova [2]);

- component of information culture (A. A. Temerbekova and G. V. Bajkunakova [3], M. V. Nepobednyj, A. P. Sysoev, and E. A. Mramornova [4], A. Z. Takov [5]);

- the process of mastering the graphic language, the skills of operating with graphic information and the ability to use it in various areas of educational activity (A. Temerbekova and G. V. Bajkunakova [3, p. 189]);

- a certain level of mastering graphic methods and methods of transferring information, assessed by the quality of execution and reading of drawings I. V. Chugunova [2];

- algorithmic process of forming graphic skills and abilities (M. Frostig [6], I. V. Chugunova [7]);

- the ability to design and model the studied processes and phenomena using modern computer technologies (R. Yu. Ovchinnikova [8];

- a set of methods for transmitting information in a graphic way, as well as the willingness to creatively transfer the system of skills for processing visual information into various spheres of social life - graphic education (N. V. Mishina [9]).
Various ways of forming the graphic culture of school students are considered - from art technologies (A. Temerbekova and G. V. Bajkunakova [3]) to solving graphic problems and computer calculations (S. M. Ganeev [10], A. V. Kostrjukov, S. I. Pavlov, and Ju. V. Semagina [11], I. S. Jakimanskaja [12].

The analysis of scientific sources in the process of identifying the structural components of the graphic culture of high school students by means of computer technologies showed in various author's concepts of the interpretation of the concept of "graphic culture" the reflection of the ideas of systemic, integrative, activity and personality-oriented approaches (E. I. Purgina [13], I. V. Chugunova [14]).

Since graphic culture is a component of the general culture of a person's personality and is filled with a value sense, this phenomenon can be considered in the context of a humanitarian culture, represented by cognitive, axiological and activity-practical components, based on the triad: “cognition” (graphic knowledge), “values” (selfactualization in the process of creating a graphic (creative) product, pre-professional orientation), "experience" (graphic skills and abilities, activities), in accordance with the norm-regulating, culture-creating and socializing functions [15].

The above ideas are illustrated in "Fig. 1" (Authors).

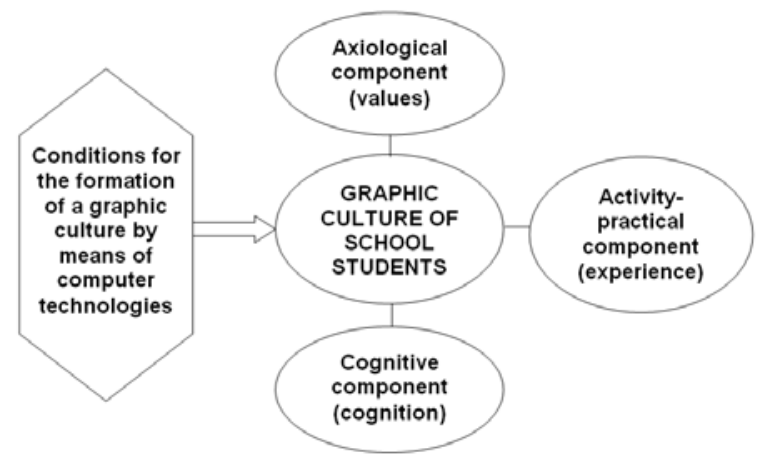

Fig. 1. Structural model of the graphic culture of the student.

Since in the research it is computer technologies that act as a means of forming a graphic culture, it is necessary to note some advantages and barriers of their application in teaching [16] - [17]:

1) barriers are associated both with restrictions due to the requirements for working on a personal computer and with a shortage of software; in some cases, they point to the problems of material and technical equipment of the educational process;

2) speaking about the advantages, they emphasize the "convertibility" of such education (the competitiveness of a specialist who owns information technologies, the availability of information retrieval systems, the possibility of modeling cognizable objects). 
Since, in the opinion of the pedagogical community, among school subjects, it is in drawing lessons that the tasks of forming a graphic culture are priority solved, and drawing is one of the few academic disciplines that optimally correlate with computer learning technologies, a restriction was introduced into the study: the stated hypothetical conditions were implemented in drawing lessons.

Table 1 presents the content (Authors and L. V. Brykova [18]) of each component of the graphic culture formed within the framework of drawing lessons in grades 10-11.

TABLE I THE CONTENT OF THE STRUCTURAL COMPONENTS OF THE STUDENT'S GRAPHIC CULTURE

\begin{tabular}{|l|l|}
\hline $\begin{array}{c}\text { The structural } \\
\text { component of the } \\
\text { student's graphic } \\
\text { culture }\end{array}$ & \multicolumn{1}{|c|}{ Component content } \\
\hline $\begin{array}{l}\text { Cognitive } \\
\text { component }\end{array}$ & $\begin{array}{l}\text { Graphic thesaurus; knowledge of the } \\
\text { general rules for drawing up a drawing and } \\
\text { types of drawings; knowledge of the types } \\
\text { of computer graphics, understanding of the } \\
\text { designs of technical devices. }\end{array}$ \\
\hline $\begin{array}{l}\text { Axiological } \\
\text { component }\end{array}$ & $\begin{array}{l}\text { Graphic aesthetics; activity in solving } \\
\text { graphic problems; the ability to apply } \\
\text { graphic knowledge in new situations when } \\
\text { solving problems with creative content. }\end{array}$ \\
\hline Activity-practical & $\begin{array}{l}\text { Ability to reproduce images of technical } \\
\text { objects in a drawing, skill in graphic } \\
\text { constructions, proficiency in applied } \\
\text { graphic programs. }\end{array}$ \\
\hline
\end{tabular}

The first condition is the use of a complex of software, methodological and pedagogical teaching aids using computer technologies. The clarification of the program content was associated with the possibilities of using CAD - computer-aided design systems: AutoCAD and KOMPAS 3D programs. These programs provide an opportunity to implement integrative ties in a new way in teaching subjects such as drawing, mathematics, computer science.

It is important to note the need to use both traditional (textbooks, test materials, visual aids) and modern computer tools, because, according to O. V. Shtejmark [19], using only computer tools does not fully solve informative, communicative and educational tasks. Electronic testing programs such as “AISST”, “Airen”, "Test Constructor”, "EasyQuizzy” and others can be used to control the knowledge of students.

The second condition is the implementation of an active learning model in the organization of educational activities and interaction between the teacher and students in the classroom. The scientific and pedagogical community [4] believes that the explanatory-reproductive method of teaching still dominates in schools, which does not contribute to maintaining interest in cognition, since there is no problem in it, the opportunity for the student to experience an intellectual sense of delight from the independent solution of graphic problems. The formation of the graphic culture of school students, according to scientists (I. V. Chugunova [2], [7], A. Z. Takov [5], B. F. Lomov [20]), will not be effective without the problematic nature and personification of the teaching content.

The organization of the process in this direction involves the active use of technologies such as project activities, design analysis, portfolio, and technologies for the development of critical thinking, which are largely aimed at interaction, self-control and self-presentation of students.

\section{RESULTS AND DISCUSSION}

These conditions were created in the course of the implementation of the elective course "Technical drawing using CAD” for grades 10-11 (the course was compiled in accordance with the program content of the textbooks V. V. Stepakova, L. V. Kurcaeva, M. A. Ajgunjan and others [21] and the program V. V. Stepakova, A. P. Boguslavskij [22].

The course, in addition to organizing an effective process of forming a graphic culture, is aimed at deepening and expanding the content of the basic drawing program of the basic school and is designed for 130 hours, 65 hours per academic year, 2 hours a week.

The course consists of an introduction and three sections:

- maintenance: the concept of the Unified System for Design Documentation, the drawing of a part as the basis of graphic documentation (1 hour);

- Section 1: the concept of a part and an assembly unit (5 hours);

- Section 2: detachable and one-piece connections of parts in the drawings (26 hours);

- Section 3: reading drawings, development of design documentation in AutoCAD and KOMPAS 3D (96 hours).

Under the conditions of the experiment, conditions were created to increase the level of the graphic culture of students: a program for the formation of a graphic culture was developed and implemented, including a description of the system of activities and interaction between the teacher and students in the lesson, a system for monitoring and assessing the level of formation of the graphic culture of students; the didactic capabilities of computer technologies, contributing to the formation of graphic culture, are determined. Thus, a system of methodological support for the development of the graphic culture of students was developed and implemented.

The formation of the levels of graphic culture, as multicomponent formations, occurs in the course of the 
interaction of individual parameters. The following parameters are highlighted:

- reproductive level - knowledge of the general rules for drawing up a drawing and types of drawings, skills in graphic constructions;

- productive level - knowledge of the general rules for drawing up a drawing and types of drawings, skills of graphic constructions, the ability to reproduce images of technical objects in a drawing, a graphic thesaurus, knowledge of types of computer graphics, graphic aesthetics;

- creative level - knowledge of the general rules for drawing up a drawing and types of drawings, skills in graphic constructions, the ability to reproduce images of technical objects in a drawing, a graphic thesaurus, knowledge of types of computer graphics, understanding of designs of technical devices, graphic aesthetics, knowledge of applied graphic programs.

All parameters of the levels of graphic culture are taken equal, therefore the level of graphic culture is determined by formula 1 , created by the authors:

$$
I I=\frac{1}{8}(\mathrm{P} 1+\mathrm{P} 2+\cdots+\mathrm{P} 8)
$$

where P1 - knowledge of the general rules for drawing up a drawing and types of drawings, P2 - graphic construction skills, P3 - the ability to reproduce images of technical objects in the drawing, P4 - graphic thesaurus, P5 - knowledge of types of computer graphics, P6 understanding the structures of technical devices, P7 graphic aesthetics, P8 - possession of applied graphics programs, II - integral indicator.

The Pi parameters were determined as the ratio of the number of correct test answers to the total number of questions.

The study was conducted on the basis of the Municipal Budgetary Educational Institution "Secondary School No. 24 named after L.I. Malyakov”, Pskov in the control (28 subjects) and experimental (28 subjects) samples. 10 lessons were held according to the thematic plan of the course "Technical drawing using CAD”.

Determination of the level of graphic culture formation in the control and experimental groups of school students by eight differentiated parameters at the beginning and at the end of the experiment included eight tests, consisting of a total of 69 questions and tasks. Data analysis confirms the effectiveness of the proposed conditions for the formation of a graphic culture, implemented within the framework of a special elective course. Positive dynamics is visible in all parameters ("Fig. 2" (Authors)).

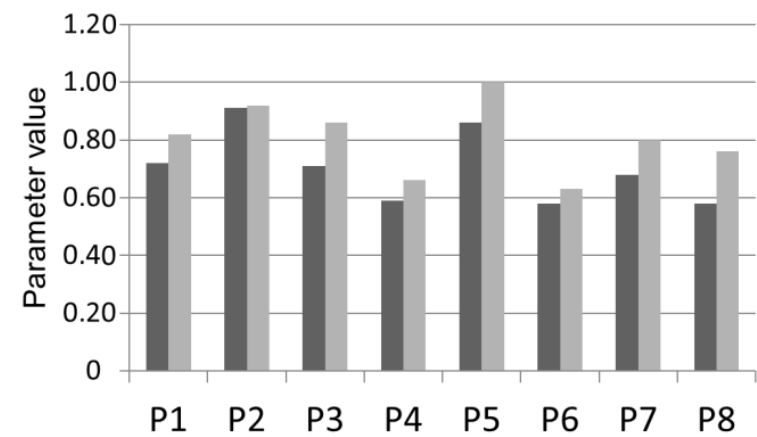

Fig. 2. Results of determining the parameters of graphic culture.

Fig. 3 (Authors) illustrates an increase in the level of graphic culture of the experimental sample, compared with the control, within the productive level. At the same time, the levels were initially measured as equal.

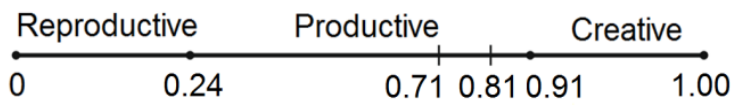

Fig. 3. The level of graphic culture of the experimental $(0,807)$ and control $(0,705)$ sample.

Thus, the complex of software, methodological and pedagogical teaching aids using computer technologies, developed taking into account the requirements for creating special pedagogical conditions, contributes to the formation and development of graphic culture in drawing lessons among school students of the experimental sample.

\section{CONCLUSIONS}

Graphic culture is a multifaceted sociocultural phenomenon. The formation of the graphic culture of students is the process of developing the experience of transforming graphic objects and mastering the graphic language, which is used in technology, science, production, design, and other areas of activity, which is currently not effective enough. The main reason for this situation is that not all computer technologies at school have found their proper application, and the existing methodology and organization of teaching at school do not fully contribute to ensuring the interest and motivation of students in obtaining a high level of knowledge in drawing.

With regard to school teaching, the level of formation of graphic culture is assessed through the ability to consciously apply graphic knowledge, skills and abilities, as well as the ability to navigate in the environment of graphic information technologies. In the study, the graphic culture of school students is understood as a set of educational and personal achievements of students in the field of mastering and using graphic methods of transforming information. 
The analysis of educational and methodological works and scientific works in the field of personification of school students' education shows that the process of forming the graphic culture of school students can be successful only if a certain complex of pedagogical conditions is created, aimed at solving the problems of the content and organization of training, taking into account the structure of graphic culture, represented by cognitive, axiological and activity-practical components.

Experimental work on the implementation in practice of the course on the formation of graphic culture using computer tools demonstrates the effectiveness of the proposed pedagogical conditions.

\section{ACKNOWLEDGMENTS}

The authors are grateful to the teaching staff and high school students of the Municipal Budgetary Educational Institution "Secondary School No. 24 named after L. I. Malyakov", Pskov for the opportunity to experimentally test the pedagogical conditions for the formation of the graphic culture of school students in the process of using computer technologies.

\section{REFERENCES}

[1] Je. E. Platonova, "Culturology": textbook [Э. Е. Платонова, "Культурология": учебное пособие], M: Academic project; Tradition, 2003. (in Russian)

[2] I. V. Chugunova, "Graphic culture as a subject of scientific knowledge, Information and education: the boundaries of communication" [И. В. Чугунова, "Графическая культура как предмет научного знания, Информация и образование: границы коммуникаций"], no. 4 (12), pp. 146-150, Apr. 2012. Available: https://elibrary.ru/item.asp?id=22889305 [Accessed May 23, 2020]. (in Russian)

[3] A. A. Temerbekova and G. V. Bajkunakova, "Formation of the graphic culture of schoolchildren - creativity - art design. Didactics of secondary and high schools" [А. А. Темербекова, Г. В. Байкунакова. "Формирование графической культуры школьников - творчество - арт-проектирование. Дидактика средней и высшей школы"], Bulletin TGPU, no. 5(194), pp. 189193, $2018 . \quad$ Available: https://cyberleninka.ru/article/n/formirovanie-graficheskoykultury-shkolnikov-tvorchestvo-art-proektirovanie [Accessed May 23, 2020], https://doi.org/10.23951/1609-624X-2018-5-189-193 (in Russian)

[4] M. V. Nepobednyj, A. P. Sysoev, E. A. Mramornova, "Pedagogical model of the development of graphic and technological culture among students in secondary schools" [M. В. Непобедный, А. П. Сысоев, Е. А. Мраморнова, "Педагогическая модель развития графической и технологической культуры у обучающихся в средних общеобразовательных школах"], Scientific and methodological electronic journal «Koncept», no. 31, pp. 61-65, 2017. [Online]. Available: http://e-koncept.ru/2017/970027.htm [Accessed Sept. 3, 2020]. (in Russian)

[5] A. Z. Takov, "The problem of the development of graphic culture among students in the scientific and pedagogical literature. Problems of modern pedagogical education" [А. 3 Таков, "Проблема развития графической культуры у студентов в научно-педагогической литературе. Проблемы современного педагогического образования"], no. 64(2), pp. 179-181, 2019. Available: https://cyberleninka.ru/article/n/problema-razvitiyagraficheskoy-kultury-u-studentov-v-nauchno-pedagogicheskoyliterature [Accessed Sept. 29, 2019]. (in Russian)
[6] M. Frostig, Program for the Development of Visual Perception. N. Y., 1979.

[7] I. V. Chugunova, "Organizational and pedagogical conditions for the formation of the graphic culture of high school students" [И. В. Чугунова, "Организационно-педагогические условия формирования графической культуры старшеклассников"], Dissertation, Barnaul State Pedagogical University, Gorno-Altajsk, Russia, 2008. (in Russian)

[8] R. Yu. Ovchinnikova, "Graphic design in the context of visual culture and new technologies" [Р. Ю. Овчинникова, "Графический дизайн в контексте визуальной культуры и новых технологий"], Manuskript, vol. 12, no. 5, pp. 188-192, Мау 2019. [Online]. Available:

https://cyberleninka.ru/article/n/graficheskiy-dizayn-v-kontekstevizualnoy-kultury-i-novyh-tehnologiy [Accessed Oct. 12, 2005], https://doi.org/10.30853/manuscript.2019.5.40 (in Russian)

[9] N. V. Mishina, "Pre-professional development of adolescents' graphic skills in the context of an integrative approach" [H. B. Мишина, "Предпрофессиональное развитие графических умений подростков в контексте интегративного подхода"], Naukovedenie, vol. 7, no. 4(29), July- August, 2015. [Abstract]. Available: https://cyberleninka.ru/article/n/predprofessionalnoerazvitie-graficheskih-umeniy-podrostkov-v-konteksteintegrativnogo-podhoda [Accessed Dec. 19, 2019]. (in Russian)

[10] S. M. Ganeev, "Formation of graphic literacy of students when teaching the solution of planimetric problems in conditions of computer support" [C. М. Ганеев, "Формирование графической грамотности учащихся при обучении решению планиметрических задач в условиях компьютерной поддержки"], Thesis of dissertation, Omsk State Pedagogical University, Omsk, Russia, 2004. (in Russian)

[11] A. V. Kostrjukov, S. I. Pavlov, and Ju. V. Semagina, "Modern aspects of geometric-graphic culture. The university complex as a regional center of education, science and culture: materials" [A. B. Кострюков, С. И. Павлов, Ю. В. Семагина, "Современные аспекты геометро-графической культуры. Университетский комплекс как региональный центр образования, науки и культуры"], Materials of the All-Russian scientific and methodological conference, 3-5 Febr. 2016, Orenburg, Russia. Orenburg: Orenburg. gos. un-t., 2016. (in Russian)

[12] I. S. Jakimanskaja, "Development of spatial thinking of schoolchildren" [И. С. Якиманская, "Развитие пространственного мышления школьников"]. M: Pedagogika, 2015. (in Russian)

[13] E. I. Purgina, "Methodological approaches in modern education and pedagogical science: textbook" [Е. И. Пургина, "Методологические подходы в современном образовании и педагогической науке: учебное пособие "], Ekaterinburg: Ural state pedagogical university, 2015. (in Russian)

[14] I. V. Chugunova, "A systematic approach to the concept of "graphic culture" schoolchild" [И. В Чугунова, "Системный подход к понятию "графическая культура" школьник"]. Vestnik TGU. Bulletin of operational scientific information "Actual problems of philology and pedagogy", no. 71, pp. 105-112, 2006. (in Russian)

[15] N. I. Jeliasberg, "Humanitarian culture of the individual - the basis and purpose of modern education" [H. И. Элиасберг, "Гуманитарная культура личности - основа и цель современного образования"], SPb.: Publishing house «Sojuz», 2008. (in Russian)

[16] A. Ju. Uvarova, I. D. Frumina, "Difficulties and prospects of digital transformation of education" [А. Ю. Уварова, И. Д. Фрумина, "Трудности и перспективы цифровой трансформации образования"]. M: Publishing House of the Higher School of Economics, 2019. (in Russian)

[17] S. Pejpert, "The basics of using information technology" [C. Пейперт, "Основы использования информационных технологий"], M: Prosveshhenie, 2006. (in Russian) 
[18] L. V. Brykova, "Formation of graphic culture of students of a technical university in the process of professional training" [Л. В. Брыкова, "Формирование графической культуры студентов технического вуза в процессе профессиональной подготовки"], Dissertation, Kursk State University, Kursk, Russia, 2011. (in Russian)

[19] O. V. Shtejmark, "Pedagogical conditions for the effective use of computer technologies in the pedagogical process" [O. B. Штеймарк, "Педагогические условия эффективного использования компьютерных технологий в педагогическом процессе"], Knowledge. Understanding. Skill, no. 1, pp. 211-215, 2008. Available: https://cyberleninka.ru/article/n/pedagogicheskieusloviya-effektivnogo-ispolzovaniya-kompyuternyh-tehnologiy-vpedagogicheskom-protsesse [Accessed Sept. 3, 2020]. (in Russian)
[20] B. F. Lomov, "Questions of general, educational and engineering psychology" [Б. Ф. Ломов, "Вопросы общей, педагогической и инженерной психологии"], M: Pedagogika, 1991. (in Russian)

[21] V. V. Stepakova, L. V. Kurcaeva, M. A. Ajgunjan and others, "Drawing": textbook [В. В. Степанкова, Л. В. Курчаева, М. А. Айгунян и др., "Черчение": учеб.пособие], M: Prosveshhenie, 2013. (in Russian)

[22] V. V. Stepakova, A. P Boguslavskij, "Drawing with elements of computer graphics" [В. В. Степакова, А. П. Богуславский, "Черчение с элементами компьютерной графики"]. М: Prosveshhenie, 2009. (in Russian) 